\title{
Hygrothermal simulation of building performance: data for Scottish masonry materials
}

\author{
P. F. G. Banfill $\mathbb{C}$
}

Received: 21 October 2020/ Accepted: 22 July 2021 / Published online: 3 August 2021

(C) The Author(s) 2021

\begin{abstract}
Retrofitting thermal insulation to solid masonry walls alters their hygrothermal behaviour, which can be modelled by hygrothermal simulation software. However, such software needs values of key material properties to ensure satisfactory results and until now data has not been available for Scottish masonry buildings. This work aims to contribute to a Scotland-specific dataset of material properties for use by designers working on such buildings. Thermal conductivity, water vapour permeability, sorptivity, water absorption coefficient, hygroscopic sorption, density and porosity were all determined experimentally for selected historic and contemporary masonry materials. Within the range of materials tested three groups of materials properties emerge. Natural hydraulic lime mortars, hot-mixed quicklime mortar and earth mortar all show comparatively low density, high porosity, low thermal conductivity, high water vapour permeability and variable but generally high hygroscopic sorption. Craigleith, Hailes and Giffnock sandstones, no longer available but obtained from conservation works on historic buildings, and Locharbriggs and Hazeldean sandstones, obtained from current production, all show intermediate values of these properties. Crathes granodiorite and Scottish whinstone (from current production) show high
\end{abstract}

P. F. G. Banfill $(\bowtie)$

School of Energy, Geoscience, Infrastructure and Society, Heriot-Watt University, Edinburgh EH14 4AS, UK

e-mail: p.f.g.banfill@hw.ac.uk density, low porosity, high thermal conductivity, low water vapour permeability and low hygroscopic sorption. It is shown that these materials are all relevant to Scottish buildings constructed in traditional masonry and this paper presents the first comprehensive set of hygrothermal property data for them.

Keywords Hygrothermal properties - Lime mortar · Sandstone · Granite - Whinstone

\section{List of symbols}

$a, b, c \quad$ Coefficients in a polynomial function

A Water absorption coefficient $\left(\mathrm{kg} /\left(\mathrm{m}^{2} \sqrt{\mathrm{s}}\right)\right)$

$D_{w s} \quad$ Liquid transport suction coefficient $\left(\mathrm{m}^{2} / \mathrm{s}\right)$

$R^{2} \quad$ Coefficient of determination in linear regression (dimensionless)

$S \quad$ Sorptivity $(\mathrm{mm} / \sqrt{ } \mathrm{min})$

$w \quad$ Water content $\left(\mathrm{kg} / \mathrm{m}^{3}\right)$

$w_{f} \quad$ Free water content at saturation $\left(\mathrm{kg} / \mathrm{m}^{3}\right)$

$x, x_{i j} \quad$ Measured values

$\bar{x}, \bar{x}_{i j} \quad$ Means of measured values

$\delta_{\text {dry }} \quad$ Water vapour permeability (dry cup test) $(\mathrm{kg} /$ $(\mathrm{m} \mathrm{sec} \mathrm{Pa})$ )

$\delta_{\text {wet }} \quad$ Water vapour permeability (wet cup test) $(\mathrm{kg} /(\mathrm{m} \mathrm{sec} \mathrm{Pa}))$

$\varepsilon_{\text {MIP }} \quad$ Porosity by mercury intrusion porosimetry (dimensionless)

$\phi \quad$ Relative humidity (\%)

$\lambda_{0} \quad$ Dry thermal conductivity $(\mathrm{W} /(\mathrm{mK}))$ 
$\lambda_{\text {sat }} \quad$ Saturated thermal conductivity $(\mathrm{W} /(\mathrm{mK}))$

$\mu_{\text {dry }} \quad$ Vapour diffusion resistance factor (dry cup test) (dimensionless)

$\mu_{\text {wet }} \quad$ Vapour diffusion resistance factor (wet cup test) (dimensionless)

$\rho \quad$ Dry density $\left(\mathrm{kg} / \mathrm{m}^{3}\right)$

$\rho_{\text {sat }} \quad$ Saturated density $\left(\mathrm{kg} / \mathrm{m}^{3}\right)$

$\sigma \quad$ Standard error

$\theta \quad$ Water content $\left(\mathrm{kg} / \mathrm{m}^{3}\right)$

$\theta_{\text {sat }} \quad$ Water content at saturation $\left(\mathrm{kg} / \mathrm{m}^{3}\right)$

$\theta_{90}$ Equilibrium water content at $90 \%$ relative humidity $\left(\mathrm{kg} / \mathrm{m}^{3}\right)$

\section{Introduction}

Moisture from the external environment and generated by activities within a building can cause deterioration of the building fabric and create unhealthy indoor conditions: its management is therefore a major consideration in construction [1]. Moisture transport is closely coupled to heat transfer and together these are the subject of hygrothermal building physics [2]. Solid masonry walls "breathe" (a non-scientific term widely used to denote the ability to pass water vapour from high humidity internal spaces to the lower humidity external environment) and this is a major factor in determining the performance and durability of solid masonry construction [3-6].

About $20 \%$ of the UK's housing stock is of traditional construction with masonry walls, with higher proportions in Wales and Scotland than in England [7]. Likewise, in England and Wales, 29\% of offices and $40 \%$ of retail premises (by floor area) were built pre-1918 [8] and may be presumed to be similarly constructed. These buildings can contribute to meeting the UK Government's $\mathrm{CO}_{2}$ emissions reduction target [9] if walls are retrofitted with thermal insulation. However, this additional insulation risks upsetting the moisture equilibrium within a wall and, in fact, energy-led retrofits to improve the thermal performance of the building fabric almost always change its moisture performance [5, 10] and severe internal conditions can be created by inappropriate work [11].

Fortunately, hygrothermal building performance simulation software enables designers to assess the impact of insulation retrofits on solid walls before a project starts and helps to avoid negative effects $[12,13]$. The software requires values for material physical properties which are typically provided in a database (e.g. WUFI® [14], DELPHIN [15]). However, there are no UK masonry materials in the databases and a recent English report [16] on the risk of moisture-induced damage in buildings notes that "there is currently a lack of tested or standardised material characteristics for those typically used in the UK construction industry". Likewise, Kent, reviewing commissioned research, comments that "the accuracy of input data for hygrothermal modelling ... is compromised by the lack of historic material testing" [17]. The use of inappropriate values for these properties could lead to a wrong estimate of the condensation and/or mould growth risk in an insulated wall [18].

Since the reliability of a hygrothermal simulation depends critically on appropriate input data, the aim of this work is to contribute to the first Scotland-specific data set of material properties for use by designers to ensure that retrofits do not harm traditional masonry buildings in achieving energy efficiency.

\section{Literature review}

\subsection{Materials for traditional masonry buildings} in Scotland

The materials for this study were selected on the basis of their relevance to the energy-led retrofitting and/or alteration of traditionally constructed or historic masonry buildings in Scotland. This section gives a brief justification for their choice. Whereas other materials are visible in the Scottish built environment [19], they are outside the scope of this initial investigation.

The performance of traditional masonry is significantly influenced by the choice of bedding and jointing mortar, which may account for up to $40 \%$ of the volume of the wall. Natural hydraulic limes (NHLs) have been used extensively in mortar for repairs to historic masonry once it was recognised that the high strength, high modulus of elasticity and impermeability of Portland cement mortar had led to severe damage to stone facades [20]. Mortars using NHL2, NHL3.5 and NHL5 (classifications according 
to BS EN 459-1 [21]) from St Astier, France were chosen for this study because of the binders' consistent composition and performance, which have led to these materials being prominent in Scottish building conservation. However, it has recently been argued that NHL mortars are less historically authentic than hotmixed lime mortars [22]. Reviewing over 600 analyses of Scottish historic lime mortars from all kinds of bedding, jointing and rendering applications, Torney et al. [23] note that $77 \%$ used a non-hydraulic or feebly hydraulic binder, whereas $18 \%$ contained moderately hydraulic and only $6 \%$ eminently hydraulic binder. Hot-mixed lime mortars were extensively used in the past, especially where hydraulic limes were not available: $74 \%$ of the non- to feebly-hydraulic lime mortars used quicklime [23]. Typically quicklime (high purity $\mathrm{CaO}$ ) was blended with sand and water and used by the masons either immediately or after storage in airtight containers. For this reason hotmixed lime mortars are also termed quicklime mortars. Lime mortars harden by atmospheric carbonation of calcium hydroxide and by hydration of any hydraulic components, such as dicalcium silicate [20]. Because carbonation is slow it is possible for the core of a wall to remain uncarbonated for many years, even though the mortar at the surface is fully carbonated. For this reason, the lime mortars in this programme were tested in both the uncarbonated and carbonated states, enabling any observed differences to be taken into account in hygrothermal simulations. Finally, earth mortars (defined as a blend of clay, silt and sand) were used in Scotland in masonry that would typically be protected by a lime-based render [24, 25]. For these reasons NHL mortars, hot-mixed lime mortar and earth mortar were all included in this programme, but no historic mortars were collected from existing buildings.

The principal building stones used in Scotland were sandstone, granite and whinstone: the available limestone beds are generally too thin to be useful sources of building stone but were extensively worked for lime burning [26]. Three historic sandstones were used in this programme because of their prominence in Scotland's traditional masonry. Craigleith sandstone was quarried for over 300 years till 1922 and was extensively used in Edinburgh for ashlar in prestigious buildings such as Register House, University of Edinburgh's Old College and the National Monument on Calton Hill, as well as the residential terraces of
Charlotte Square. The quarry (about $3 \mathrm{~km}$ west of the city centre) was infilled with inert waste during the twentieth century and the stone is no longer available [27]. Craigleith is a pale cream-grey and fine textured carboniferous sandstone, rich in quartz, and was highly prized because of the large sized blocks that could be extracted. In addition, a so-called "Feak" stone, a lower quality ripple bedded sandstone, was produced from parts of the same quarry. Derived from the same Lower Carboniferous deposits, Hailes sandstone (obtained for over 300 years till 1920 from a now-infilled quarry $5 \mathrm{~km}$ south west of Craigleith), was, in contrast, thinly bedded and with a laminated structure, making it unsuitable for ashlar work. Nevertheless, it was in high demand for steps, paving, foundations and especially squared rubble (e.g. for internal surfaces and walls that would be finished in lime plaster). Hailes sandstone could be white, grey/ blue or even pink with wispy ripple laminations of irregular micaceous or carbonaceous material [26], visually similar to the Feak stone from Craigleith. Giffnock sandstone was extracted from several quarries, one of which was underground, between 1835 and 1912 and was widely used in Glasgow (e.g. Kelvingrove Art Gallery and Museum, parts of the University of Glasgow and many buildings designed by Alexander Thomson, who was part owner of one quarry) and also shipped to Northern Ireland, where it is identified in 65 buildings [28]. The quarries (about $7 \mathrm{~km}$ south of Glasgow city centre) were infilled with waste during the twentieth century and the stone is no longer available. Giffnock is a blonde carboniferous sandstone, rich in quartz and the so-called "Liver" rock was especially prized, being a thick bedded freestone, comparatively easy to work [29].

Two contemporary sandstones were used in this programme. Locharbriggs sandstone has been extracted since 1890 and used extensively in southern Scotland and northern England, with limited use in Northern Ireland. It is a Permian aeolian sandstone ("Old Red Sandstone"), fine to medium grained with quartz grains coated in iron oxide, which confers the characteristic red colour, and cemented by silica but with clearly defined bedding/lamination structures where clay minerals are concentrated [28]. Hazeldean sandstone, marketed as an excellent visual and geological match for Craigleith sandstone for repairs and extensions [30], was quarried $8 \mathrm{~km}$ north of Alnwick, Northumberland, in the 1800s and reopened in 2010. It 
is also from the Lower Carboniferous, fine to medium grained with white to light grey and buff varieties produced, having a uniform texture with evidence of slight bedding.

Aberdeenshire granites have a long history of use in north-east Scotland. Defined as medium to coarse grained light coloured igneous rocks, they contain at least $5 \%$ quartz and $55-75 \%$ silica in various forms. They are very strong and durable, as well as being capable of being polished for ornamental monuments, etc. From 1741 Rubislaw quarry (6 km west of Aberdeen city centre) supplied a grey, muscovitebiotite granite to Aberdeen and abroad as building stone, for monuments and for street paving blocks until its closure in 1971, during which time it acquired a reputation as the deepest hole in Europe, and is now partially filled with water [26, 31]. As a result of its extensive use Aberdeen was nicknamed "The Granite City" but according to McMillan [26] other quarries which formerly supplied building stone continue to produce roadstone and concrete aggregate. Craigenlow (23 km west of Aberdeen) is one such, producing building stone from 1878 to 1939 , and subsequently extended for roadstone production. It was chosen for this programme as a convenient source of granodiorite, part of the Crathes pluton, which is a close geological match to Rubislaw granite.

Whinstone is a quarry industry term for any dark coloured rock, such as basalt or dolerite, but according to McMillan et al. [32], dolerite sill, a coarse grained dark grey igneous rock of volcanic origin, was known in Edinburgh as whinstone and was used extensively in pavings and as rubble in walls throughout Lowland Scotland. Scottish Whinstone is currently marketed as a "hard, attractive and versatile quartz-dolerite, dark grey with some lighter variations, for use in pavings, ashlar and rubble walling" [33]. It is sourced from loose boulders on farmland in the Central Belt of Scotland (rather than from bedrock at one location). As a result the geological provenance of each boulder cannot be verified without analysis, and within multiple boulders some degree of variability in rock type is likely (personal communication, L. AlbornozPerez, February 24th, 2020). It was chosen for this programme as being representative of this type of material and in current use.

\subsection{Previous investigations of hygrothermal properties}

WUFI ${ }^{\circledR}$ [14], building upon the work of Künzel [34], lists the physical properties required for hygrothermal simulation-density, thermal conductivity, water vapour permeability, water vapour diffusion resistance factor, water absorption coefficient, sorptivity, hygroscopic sorption and porosity-but few references report the whole range required for masonry and none provide them for Scottish materials. However, some research into treatments applied to masonry materials generated property data for the reference materials: these sources are described here.

Lime mortar has been widely reported. The WUFI ${ }^{\circledR}$ database [14] gives values for (i) fine, (ii) coarse hydraulic lime mortar and (iii) fine lime mortar, but no details of their composition are given. Investigating inter-laboratory variability, Lopez et al. [35] report all properties except porosity of a manufactured mortar which is "dry fabricated with pure air-slaked lime, with pozzolanic effect, inorganic fibres and sand from limestone rocks" with no details given. As part of a cultural heritage investigation, Loureiro et al. [36] report porosity and water absorption coefficient of five lime mortars collected from eighteenth-nineteenth century buildings in Brazil. Seeking improved performance of conservation mortars, Faria et al. [37] quote density, porosity and water absorption coefficient of three lime mortars from Portugal, made from dry hydrated lime powder, and from a putty obtained by slaking quicklime for 10 and 16 months in water. Summarising the results of several Portuguese investigations on lime-based mortars for rendering repairs on historic buildings, Veiga et al. [38] report water vapour diffusion data and water absorption coefficient of four hydraulic lime mortars, an air lime mortar and two blended air/hydraulic lime mortars. Unfortunately, they quote the permeability (sic) as "air thickness of equivalent diffusion" and this cannot be converted to water vapour diffusion resistance factor without knowledge of the thickness of the specimens tested, which is not given in the paper. In a series of papers on the effect of pozzolanas, Vejmelkova et al. [39] and Cachova et al. [40] report all the required properties of three different air lime mortars from the Czech Republic, with thermal conductivity and hygroscopic sorption of another one additionally reported by Cerny et al. [41]. Padfield gives density, water vapour 
permeability, water vapour diffusion resistance factor and hygroscopic sorption of an unspecified Danish lime mortar [42]. Fusade et al. [43] blended wood ash with one UK air lime and one NHL3.5 and quote the porosity, water absorption coefficient, water vapour permeability and water vapour diffusion resistance factor of the reference mortars. Grilo et al. [44] report density and porosity of one NHL3.5 mortar under various curing conditions. Additionally, Belgian, Dutch and German national standards quote density, thermal conductivity and sometimes water vapour diffusion resistance factor of unspecified lime mortar, as compiled by the International Energy Agency [45], who also report values of every required property of a mortar but without specifying whether cement- or lime-bound, a significant practical distinction. There seems to be no literature dealing with the relevant properties of lime mortar, where the state of carbonation is made clear: possibly some of the historic mortars tested by Loureiro et al. [36] were carbonated but no information is given.

Information on earth materials in WUFI ${ }^{\circledR}[14]$ is limited to a "clay mortar", a "mud plaster" and two soils from USA ("clay" and "clay loam") and no compositions are given: indeed it is not clear how these materials differ. Cagnon et al. [46] report density, thermal conductivity, water vapour permeability, water vapour diffusion resistance factor and hygroscopic sorption of five unfired earth bricks (blends of clay, silt and sand) from brickmakers in southern France. Lima et al. [47] report density, thermal conductivity, water absorption coefficient, hygroscopic sorption and porosity of earth plasters prepared with different clays, silt and sand.

Sandstone is prominent in the literature. In addition to the information on 16 German sandstones, one Swedish and two from India in WUFI ${ }^{\circledR}[14]$, Zhao and Plagge [48] give full information on three more German sandstones and report anisotropy in the density, porosity, vapour resistance factor and water absorption coefficient of four of those listed in WUFI ${ }^{\circledR}$. Koci et al. [49] report density, porosity, thermal conductivity and vapour resistance factor of four sandstones from the Czech Republic, whilst Vejmelkova et al. [50] give more comprehensive data on three more. Mukhopadhaya et al. [51] give density, water absorption coefficient and thermal conductivity of two sandstones from Canada. Additionally, Dutch, German and UK national standards quote density, thermal conductivity and sometimes water vapour diffusion resistance factor of sandstone [45].

In contrast to the situation for sandstone, a literature search on the Scopus ${ }^{\circledR}$ database for hygrothermal properties of granite yielded only a single reference to density and porosity of two Turkish granites [52]. WUFI ${ }^{\circledR}[14]$ gives values of the required properties of one granite. Additionally, Belgian, Dutch, French, German and UK national standards quote density, thermal conductivity and sometimes water vapour diffusion resistance factor of granite [45].

\subsection{Objectives}

Noting the absence of data on Scottish materials, the objectives of this work were to determine the density, thermal conductivity, water vapour permeability, water vapour diffusion resistance factor, water absorption coefficient, sorptivity, hygroscopic sorption and porosity of lime and earth mortars, sandstones, granodiorite and whinstone. The work was carried out in two testing programmes-one dealing with laboratory prepared NHL mortars (both uncarbonated and carbonated) and one dealing with hot-mixed lime mortar (both uncarbonated and carbonated), earth mortar, the sandstones, granodiorite and whinstone.

\section{Procedures}

3.1 Materials and specimen preparation

\subsubsection{NHL mortars}

Mortars comprising NHL2, NHL3.5 and NHL5 (St Astier, France) and oven-dry siliceous sand $\mathrm{A}$ in proportions binder:sand 1:3 by volume were prepared in the laboratory by weighing, taking into account the different bulk densities of the ingredients (Table 1). Figure 1 shows the particle size distribution of the sand. $12 \mathrm{~L}$ of each mortar was mixed in a Hobart $20 \mathrm{~L}$

Table 1 Composition of laboratory NHL mortars (masses in $\mathrm{kg}$ )

\begin{tabular}{lrrr}
\hline Binder type & NHL2 & NHL3.5 & NHL5 \\
\hline Lime & 2.09 & 2.36 & 2.70 \\
Sand A & 15.20 & 15.20 & 15.20 \\
Water & 2.81 & 2.64 & 2.72 \\
\hline
\end{tabular}




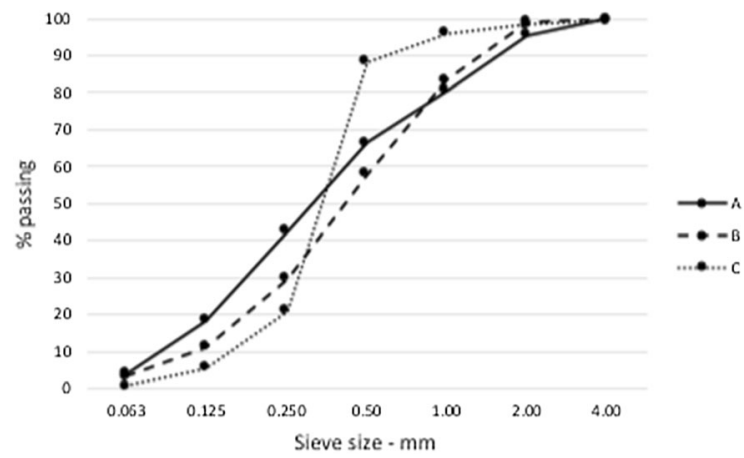

Fig. 1 Particle size distributions of the sands used in the mortars

mixer for five minutes and tested using a standard (BS EN 459-2 [53]) flow table. The water content was adjusted to achieve $150 \mathrm{~mm}$ flow (NHL2 and NHL3.5) and $160 \mathrm{~mm}$ flow (NHL5). The higher flow was chosen because the NHL5 produced a harsher mortar. Mortars were then cast into $100 \mathrm{~mm}$ cubes (steel moulds) and $360 \mathrm{~mm} \times 240 \mathrm{~mm} \times 10 \pm 1$ $\mathrm{mm}$ thick tiles (timber moulds lined with cling film). Before the mortar had set the tiles were cut into $90 \mathrm{~mm}$ diameter discs using a simple cylindrical steel "cookie cutter" device and both cubes and tiles were allowed to harden in the moulds, covered in polythene sheet, for 7 days. Each tile mould yielded eight discs and several irregularly-shaped fragments from the spaces between the discs. The specimens were demoulded and separated into two groups. Half of the cubes, discs and fragments were stored at $20{ }^{\circ} \mathrm{C}$ in airtight drums to ensure they remained saturated. The other half were transferred to a TAS Series 3 controlled environment chamber and stored at $20{ }^{\circ} \mathrm{C}, 60 \%$ relative humidity (RH) and 600 ppm $\mathrm{CO}_{2}$ until 56 days of age. These curing and exposure conditions had been used previously to ensure full carbonation of the specimens [54]. The extent of carbonation was confirmed by spraying freshly fractured surfaces with $1 \%$ phenolphthalein solution in ethanol as indicator.

\subsubsection{Hot-mixed lime mortar}

Approximately $20 \mathrm{~L}$ of hot-lime mixed mortar were collected from an active work site in Dunbar, East Lothian in 2018. The mix proportions were (by volume) 1 part kibbled quicklime (Shap Limestone, Cumbria): 2 parts sand B: 1 part sand C (Fig. 1). The mortar was prepared on site by placing water, followed by half of the sand B and all of the sand C, and finally the quicklime, in a $25 \mathrm{~L}$ capacity electric drum mixer. It was mixed for about $5 \mathrm{~min}$ and then the remainder of sand $\mathrm{B}$ added and mixed for a further $5 \mathrm{~min}$. The mixed mortar was then transported back to the laboratory and cast into $100 \mathrm{~mm}$ cubes (steel moulds) and $360 \mathrm{~mm} \times 240 \mathrm{~mm} \times 10 \pm 1 \mathrm{~mm}$ thick tiles (timber moulds lined with cling film). The moulds were filled by hand tamping, followed by just sufficient hand trowelling to ensure a smooth finish. The whole process was completed within $5 \mathrm{~h}$ of mixing. While the mortar was fresh the tiles were scored through with the point of a trowel to provide $90 \times 120 \mathrm{~mm}$ rectangular zones. The specimens and moulds were covered with cling film and placed in a high humidity environment for 17 days before demoulding. Each tile mould yielded eight tiles, at least one of which was broken into several fragments. All specimens were then placed (moist) in airtight containers for a further four weeks and then separated into two groups. Half of the cubes, tiles and fragments were placed in a TAS3 environmental controlled chamber in the same conditions as were used for the NHL mortars. The other half were left in the airtight containers to remain uncarbonated until required for testing.

\subsubsection{Earth mortar}

Approximately $20 \mathrm{~kg}$ of earth were collected from the same active work site in Dunbar in 2018. The material was salvaged from walling (thought to date from the late sixteenth century) that had been demolished as part of the restoration work. In the laboratory some vegetable matter and coarse particles of stone were removed. Mortar consisting of 1 part earth: 2 parts sand A (Fig. 1) was mixed in a Hobart bench-top mixer for $5 \mathrm{~min}$, adding water to obtain a similar workability (assessed subjectively by an experienced technician) to that of the hot-mixed lime mortar, and cast into specimen moulds, as described above for the hot-mixed lime mortar. They were hand tamped and finished with a minimum of hand trowelling, and tiles scored through as above. The compacted cubes were firm enough to be demoulded immediately and placed on a non-absorbent plate in the chamber, whilst the tiles were left in the cling film-lined moulds, and all were placed in the TAS 3 chamber at $20{ }^{\circ} \mathrm{C}, 60 \% \mathrm{RH}$ and $600 \mathrm{ppm} \mathrm{CO}_{2}$. The tiles were demoulded after 
7 days and all specimens were stored in these conditions until testing.

\subsubsection{Sandstone}

Two samples of stone removed during conservation works at Old College, University of Edinburgh, were obtained in 2018. Craigleith was taken from the external face of a wall and Craigleith (Feak)/Hailes was taken from the inside of an external wall. These designations are explained in Sect. 4.1. Some surface weathering was visible on the Craigleith sample. Samples of Giffnock stone removed during conservation works at The Lanyon Building, Queens University, Belfast, were obtained in 2018. Some surface weathering was visible. Samples of Locharbriggs stone were obtained from Cumbria Quarrying Services, Penrith in 2018. Hazeldean stone was taken from a stock supplied in 2015 by Hutton Stone, Berwick-upon-Tweed.

\subsubsection{Granodiorite}

Several irregular shaped lumps of Crathes granodiorite (about $10 \mathrm{~kg}$ each) were obtained in 2015 from Craigenlow Quarry, Aberdeenshire.

\subsubsection{Scottish whinstone}

Whinstone cubes and tiles were supplied already cut in 2019 by Tradstocks Ltd, Thornhill, Stirlingshire.

The sandstone and granodiorite samples were cut with a bench-mounted circular saw (Norton Clipper CM501) using a water-cooled diamond tipped blade. Their irregular shape prevented some samples being cut into the intended number of cubes and tiles. Also visible bedding planes in the sandstones were randomly oriented. Surface weathering was rigorously excluded from the prepared specimens. Figure 2 shows the surface appearance of the prepared stone tiles.

\subsection{Testing}

\subsubsection{Density}

The bulk density of each material, both oven dry at $105{ }^{\circ} \mathrm{C}$ (stones) or $50{ }^{\circ} \mathrm{C}$ (mortars) and saturated by immersion in water for 7 days, was determined by

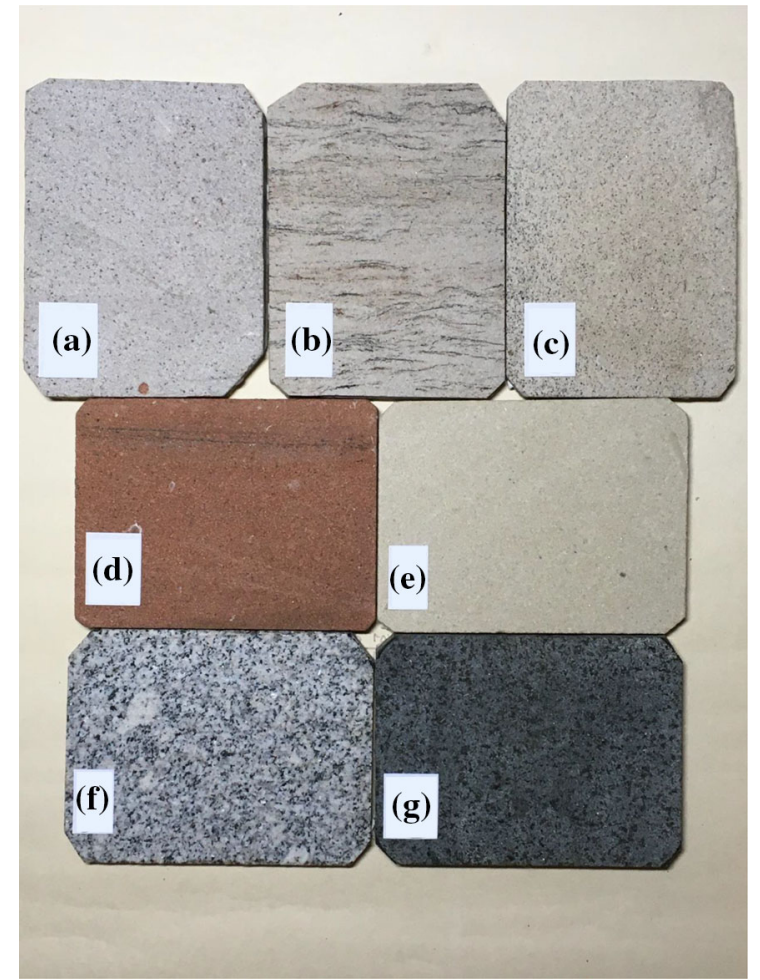

Fig. 2 Cut surfaces of the $90 \mathrm{~mm} \times 120 \mathrm{~mm}$ prepared stone specimens (Key: a — raigleith, b-Craigleith (Feak)/Hailes, cGiffnock, d-Locharbriggs, e-Hazeldean, f-Granodiorite, g-Scottish whinstone)

displacement of water. Each cube was suspended beneath an electronic balance and then weighed both in air and under water, taking care to complete the weighing quickly before significant absorption had occurred. The fragile earth mortar cubes were wrapped in cling film but were not tested in the saturated state because they disintegrated when immersed in water. The water density used in the calculation was that given for the testing temperature [55].

\subsubsection{Thermal conductivity}

The thermal conductivity was determined in both the dry and saturated conditions using the Thermtest TLS100 instrument (Thermtest inc, Fredericton, Canada) and the thermal probe method to ASTM D5334-14 [56]. The stone samples were dried to constant mass at $105^{\circ} \mathrm{C}$ and the lime and earth mortar samples were dried to constant mass at $50{ }^{\circ} \mathrm{C}$, then conditioned by room temperature exposure to $60 \% \mathrm{RH}$. A $3 \mathrm{~mm}$ groove was cut on one face of each specimen using a 
stone cutting disc mounted in a handheld angle grinder. The probe was placed in the groove, surrounded by thermal contact paste (thermal conductivity $5 \mathrm{~W} /(\mathrm{mK})$, RS Components, UK), and covered with a second specimen. This ensured that the required test condition of a minimum of $25 \mathrm{~mm}$ thickness of material around the probe was met. The test was repeated after the specimens (except earth mortar) were saturated for a week in water at room temperature.

\subsubsection{Water vapour permeability}

The water vapour permeability was determined using both dry cup and wet cup methods, broadly according to BS EN ISO 12,572:2001 [57], but because of differing availability of testing assemblies and controlled environment chamber, two methods were used. The specimen thickness was first measured with a digital calliper $( \pm 0.01 \mathrm{~mm})$ in four places, and the mean value used in calculating the results. In method 1, the $90 \mathrm{~mm}$ diameter NHL mortar discs, cured or carbonated as described above and then conditioned by exposure to $60 \% \mathrm{RH}$, were sealed into aluminium test cups (source unknown). In method 2, the cast or cut rectangular tiles of the remaining materials were conditioned to $50 \% \mathrm{RH}$ and sealed into aluminium foil trays (General Stores Ltd). In both methods, having first trimmed any irregularities in the perimeter, discs/ tiles were placed onto a narrow bead of silicone sealant (Unibond plc, UK) to create an air- and liquid-tight seal. The residual gap between the edge of the disc/tile and the wall of the cup/foil tray was sealed using molten paraffin wax (Akros Organics, Belgium). The cut stone tiles were randomly oriented with respect to any bedding planes. In dry cup tests anhydrous calcium chloride desiccant (Vida XL, UK) was placed in the cup/tray before embedding the specimen whilst in wet cup tests saturated potassium nitrate solution (Akros Organics, Belgium) was used, giving an internal atmosphere at 93\% RH [58]. It was necessary to place the desiccant or solution in a small plastic cup inside the foil tray to prevent corrosion. The assemblies (discs/tiles set in cups/trays containing desiccant/solution) were then placed in the environment chamber and weighed (to $\pm 0.01 \mathrm{~g}$ ) at intervals, recorded to within $\pm 10 \mathrm{~min}$, over several weeks. In method 1, the NHL mortar assemblies were exposed to non-standard conditions of $20^{\circ} \mathrm{C}$ and $60 \% \mathrm{RH}$ because the environment chamber was in use for other experiments at the time of the work. In method 2, assemblies comprising the remaining materials were exposed to $23{ }^{\circ} \mathrm{C}$ and $50 \% \mathrm{RH}$. In both methods the rate of mass gain or loss was determined from graphs of mass against time by linear regression. Taking account of the bedding and sealing, the exposed face area of specimens was $4574 \mathrm{~mm}^{2}$ in method 1 and $9396 \mathrm{~mm}^{2}$ in method 2, and the appropriate water vapour pressure difference for the environmental conditions was used in the calculation of permeability.

\subsubsection{Sorptivity and water absorption coefficient}

Water sorptivity [59] and water absorption coefficient were determined gravimetrically by immersing one face (measured to $\pm 1 \mathrm{~mm}$ ) of each prepared specimen or cube in water to a depth of $2 \mathrm{~mm}$ and weighing at intervals over $2-3 \mathrm{~h}$ or until water was visible on the top face, according to BS EN ISO 15,148:2002 [60]. Both water sorptivity $(\mathrm{mm} / \sqrt{ } \mathrm{min})$ and water absorption coefficient $\left(\mathrm{kg} /\left(\mathrm{m}^{2} \sqrt{\mathrm{s}}\right)\right)$ were obtained by linear regression from the slope of graphs of mass against the square root of time, divided by the measured face area. The earth mortar was not tested because it disintegrated in contact with water. However, a method of testing water-sensitive earth plaster $[47,61]$ exists: it requires care but would be suitable in future work.

\subsubsection{Hygroscopic sorption}

The moisture sorption and desorption curves were determined according to BS EN ISO 12,571:2013 [58]. Three fragments of each material, of approximately equal surface area and weighing 20-50 g, were oven dried $\left(105{ }^{\circ} \mathrm{C}\right.$ or $50{ }^{\circ} \mathrm{C}$ as appropriate) to constant mass then supported over saturated salt solutions in airtight boxes. The solutions used and their nominal relative humidities (RH) were magnesium chloride $33 \% \mathrm{RH}$, magnesium nitrate $53 \% \mathrm{RH}$, sodium chloride $75 \% \mathrm{RH}$, potassium chloride $85 \%$ RH, potassium nitrate 93\% RH [58], with the addition of pure water to give $100 \%$ RH. In each case the actual RH was measured with a handheld meter (Vaisala, Finland) and the fragments removed for weighing at intervals until constant mass was achieved (less than 7 days to reach equilibrium). Moving specimens between boxes gave the sorption curves at successively increasing RH, followed by desorption curves at 
decreasing $\mathrm{RH}$ until the final oven dried mass gave a confirmation value.

\subsubsection{Porosity}

Porosity and pore size distribution were determined by mercury intrusion using a Quantachrome PoreMaster33 instrument, using a sample cell of diameter $8 \mathrm{~mm}$ and length $20 \mathrm{~mm}$ and capillary volume of $0.5 \mathrm{ml}$, with 33,000 psi final pressure, on a single representative fragment of each material of mass approximately $2 \mathrm{~g}$. The range of pore diameters detectable with this instrument was 0.006-250 $\mu \mathrm{m}$.

\subsubsection{Petrographic analysis}

Because of the different appearance of specimens prepared from the sandstone samples taken from Old College, Edinburgh, the two stones were examined microscopically in thin section. Following vacuum impregnation of an irregular piece about 10-20 mm thick with an epoxy resin, to which fluorescent blue dye had been added, one side of the resin impregnated piece was polished and mounted on a glass slide. The mounted sample was ground and polished to about $30 \mu \mathrm{m}$ thick, prior to detailed microscopical examination under plain and polarised light following BS EN 12,407:2007 [62].

\section{Results and discussion}

\subsection{Initial comments on the Old College sandstone specimens}

When the sandstone samples from Old College, Edinburgh, were cut the specimens looked sufficiently different to raise the question of whether they were in fact different stones: weathering and applied finishes had concealed this, and the results presented below are consistently different. The sample from an external wall face is uniformly cream coloured whereas that from an internal surface of an external wall is greyer with wispy irregular and discontinuous laminae (compare tiles a and b in Fig. 2). Petrographic analysis of thin sections, performed by the Scottish Lime Centre Trust (unpublished report AP3449, 2019), characterised the two stones (shown under plane polarised light in Fig. 3) as quartz arenite [63] with (a)

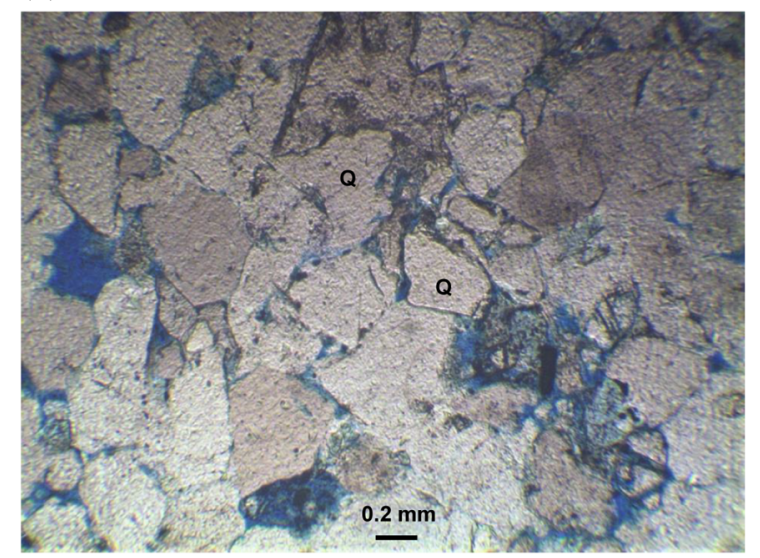

(b)

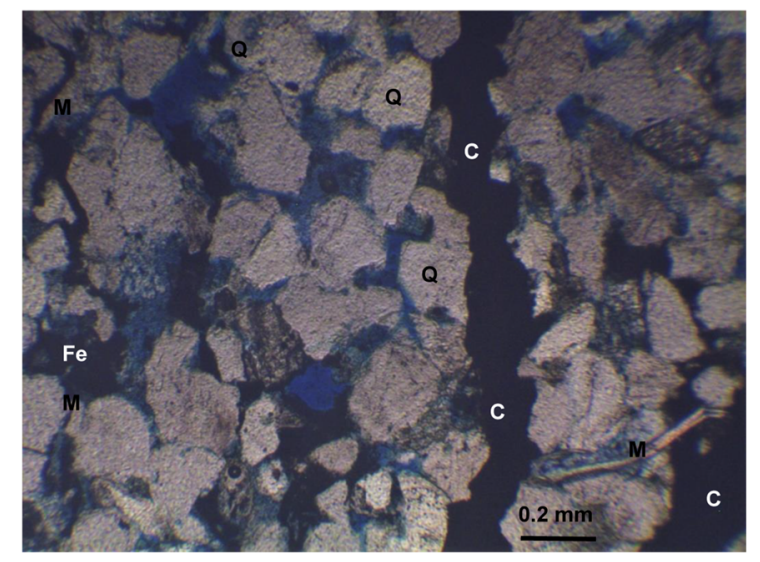

Fig. 3 Thin sections of the a Craigleith and b Craigleith (Feak)/ Hailes samples under plane polarised light. Q: quartz, M: mica, Fe: iron oxide, C: carbonaceous matter

fine to medium grain size. In both images the pores are highlighted in darker blue, whilst areas of light blue indicate pore filling clays that have absorbed some of the blue dye. The external sample (Fig. 3a) has moderately to well connected pores, with some of the larger ones filled with small, sub-angular to subrounded quartz, feldspar and lithic fragments. The sample is moderately to well sorted, showing a similar range of grain sizes, of generally fine to medium grain size. In the internal surface sample (Fig. 3b) thin carbonaceous and mica-rich laminations are evident throughout, completely blocking pores and creating barriers to flow in these regions. The majority of the matrix grains are fine to medium, creating a moderate permeability and visible porosity. By point counting, the total porosity in both sections is estimated to be 
$12-15 \%$ by volume. It was concluded that the external sample is "most likely" Craigleith stone but that the internal sample, with its ripple bedding consisting of planar concentrations of black carbonaceous fragments (clearly visible in Fig. 3b), could equally have come from two sources. It is either the Feak stone of Craigleith Quarry or from the Hailes Quarry, which are essentially indistinguishable ripple bedded sandstones. As already noted, both of these materials were widely used in Edinburgh for rubble work, foundations, steps and paving [26]. Whilst no documentary evidence is available to support this, it seems entirely reasonable that the more expensive and easily dressed Craigleith stone would be used for externally visible ashlar work and the cheaper and lower quality Craigleith (Feak) or Hailes would be used for internal rubble walling which would be concealed behind wall finishes. Therefore, in the rest of this paper these two stone samples are designated Craigleith and Craigleith (Feak)/Hailes.

\subsection{Confidence intervals in the numerical data}

Mostly three replicate specimens, prepared from the samples of materials, were tested to enable calculation of confidence intervals. The intended five replicate specimens for water vapour permeability became fewer in some cases (noted in Table 2) because of breakage, leakage or insufficient material. Mercury Intrusion Porosimetry used a single specimen.

Following the well-established statistical principles of the design and analysis of experiments [64, 65], the measurements could be evaluated by a one-way Analysis of Variance (ANOVA). In the ANOVA the overall variation is considered to be the sum of the "explained" variation due to the differences between materials and the "residual" variation due to differences in specimen preparation and handling plus the experimental error. According to Chatfield the residual is an estimate of the variance $\sigma^{2}$ in the population of measurements [65], assumed to be the same for all materials. Because significant differences between the mean values of each property are to be expected for the different materials, it is only necessary to use the ANOVA procedure to estimate the residual, and this was done as follows. If $x_{1 j}, x_{2 j} \ldots x_{i j}$ are the measured values of a property $x$ for the $i$ th test on material $j$, a total sum of squares tss can be calculated as $t s s=\sum_{i=1}^{c} \sum_{j=1}^{n}\left(x_{i j}-\bar{x}_{j}\right)^{2}$

where $c$ is the number of replicate tests and $n$ is the number of materials. Dividing this by the number of degrees of freedom gives the mean square as $t s s /(n)$ 1)) and the square root of this gives an estimate of the standard error $\sigma$. The latter can be multiplied by the appropriate value of the $t$-distribution to give the confidence interval. For $n=16$ and $\mathrm{c}=3$, the 32 degrees of freedom yield $t_{0.05}=1.69$ and the $90 \%$ confidence interval is therefore $\pm 1.69 \times \sigma$. In situations where the measured values cover a very wide range, such as the sorptivity and water absorption coefficient, a fixed confidence interval is inappropriate and a base-10 logarithmic transformation was applied to the raw data. In this case the standard error and confidence interval are equivalent to a percentage of the mean value. The confidence intervals and numbers of replicates contributing to each mean are all shown in Table 2. It should be reiterated that the confidence intervals estimated in this way are an indication of the variation between specimens of materials, manufactured or obtained at the same time from the same source for the purposes of this investigation, combined with the measurement error.

Finally the confidence intervals can be used to address the question of whether the difference between the mean values of a particular property shown by two materials is statistically significant, or could occur by chance. The Least Significant Difference is a rigorous statistical approach but, as Chatfield shows [65], it is numerically close to half the confidence interval. Therefore, in discussing the results presented in Table 2 below, the following criterion is adopted. If the mean for one material is outside the confidence interval for another then the two means are considered to be significantly different, and any smaller difference is taken to be not significant.

\subsection{Density and saturation moisture content}

Table 2 shows that the lime mortars have lower dry density $\rho_{0}$ and the granodiorite and whinstone have higher density, with the sandstones grouped between. Using the significance criterion, only Giffnock and Locharbriggs sandstones are indistinguishable. 


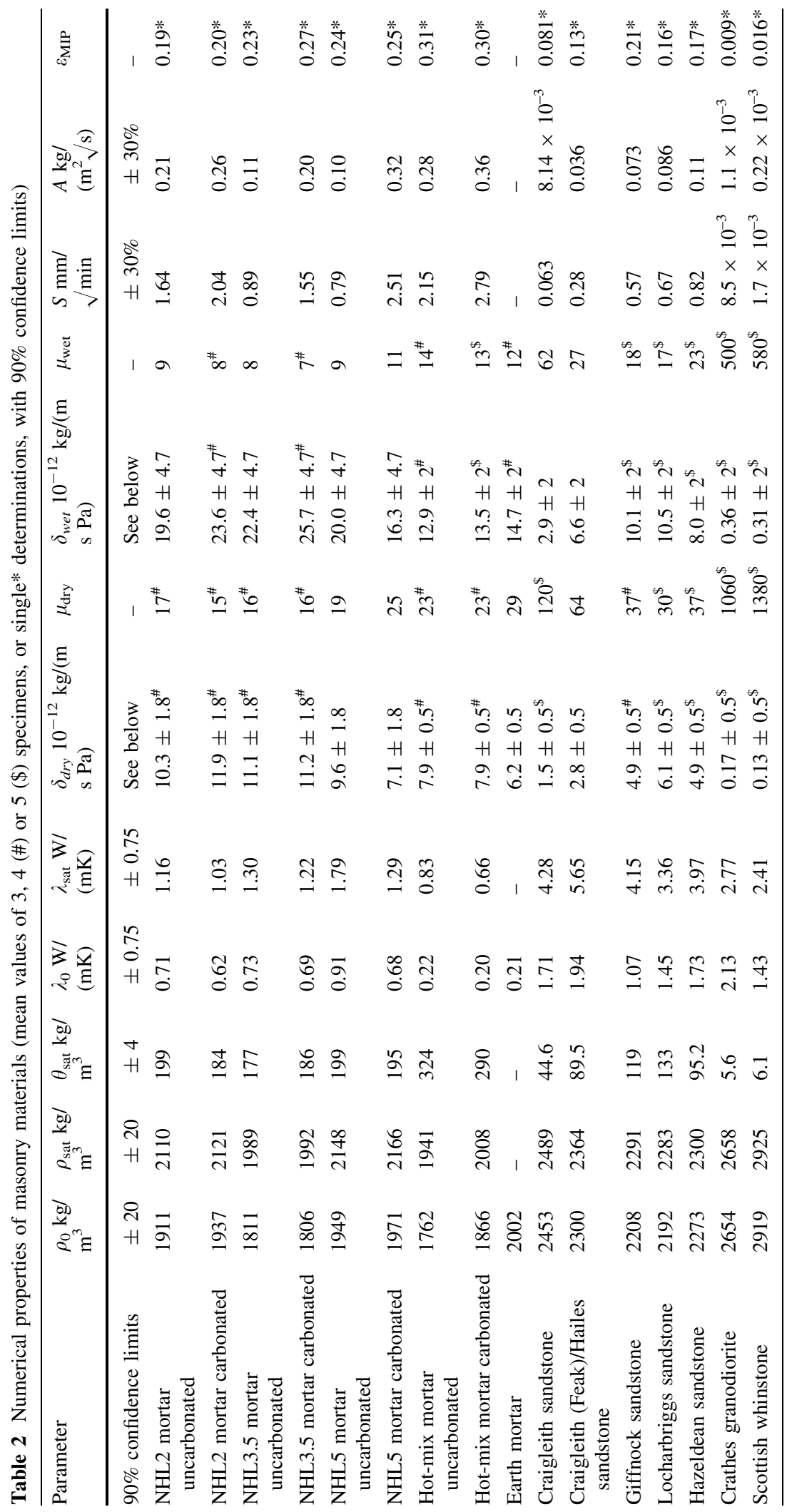


Carbonation of lime mortar tends to increase the density, with hot-mix mortar increasing over $5 \%$, but in some cases the difference is not significant, and NHL3.5 shows a decrease which is below the significance criterion. An increase would be expected from the difference between the formula weights of calcium hydroxide and calcium carbonate. As would be expected, the saturated density $\rho_{\text {sat }}$ is always higher than $\rho_{0}$ and the saturation moisture contents $\theta_{\text {sat }}$ follow the reverse order to the dry density. The less dense hotmix lime mortars are more porous and absorbent than the NHL mortars, reflecting the presence of porefilling hydrated calcium silicate in the latter.

\subsection{Thermal conductivity}

Table 2 shows that the confidence intervals in the thermal conductivity measurements are relatively wide, which suggests that the thermal probe method is subject to greater experimental error than some of the other tests. When the values are arranged in numerical order the differences between adjacent materials are not significant but among the stones the granodiorite is significantly higher than the Giffnock sandstone. The stones are generally higher than the mortars and whilst the non-NHL mortars seem lower than the NHL mortars the difference is not significant. For every stone except granodiorite and for every mortar except carbonated NHL5 and the hot-mix mortars the saturated thermal conductivity $\lambda_{\text {sat }}$ is significantly higher, as would be expected because the pores are filled with water instead of gas/vapour. The sandstones have a significantly higher saturated thermal conductivity than all the other materials.

\subsection{Water vapour permeability}

Table 2 shows that the wet cup water vapour permeability $\delta_{\text {wet }}$ is consistently higher than the dry cup value $\delta_{d r y}$ by a factor of 1.6 to 2.4. This is attributed to the enhanced transport of condensed water in capillaries at the higher RH in the wet cup test. Dry and wet cup values cover a 50-60-fold range and are highest for the NHL mortars, reflecting their high porosity and open texture, and lowest for the very dense whinstone and granodiorite, whose permeability is, in turn, less than $10 \%$ that of the least permeable sandstone. Because two different experimental procedures were followed for (i) the NHL mortars and (ii) the rest, the confidence intervals have been calculated separately and appear as such in Table 2 . In the dry cup tests, based on 16 degrees of freedom the NHL mortars exhibit confidence limits of \pm 1.8 (units of $10^{-12} \mathrm{~kg} /$ $\mathrm{m}$ sec $\mathrm{Pa}$ ), compared to \pm 4.7 in the wet cup tests, based on 14 degrees of freedom. In the dry cup tests, based on 35 degrees of freedom, the remaining materials exhibit confidence limits of \pm 0.5 , compared to \pm 2.0 in the wet cup tests, based on 29 degrees of freedom. The effect of carbonation is significant only on the NHL5 mortar but interestingly the NHL mortars are more permeable than the hot-mix lime mortars, which does not align with the differences in their density and porosity. Using the significance criterion, the NHL2, NHL3.5 and uncarbonated NHL5 mortars are indistinguishable and the carbonated NHL5 and hot-mix lime mortar are indistinguishable. Among the sandstones, Locharbriggs and Hazeldean are indistinguishable, with Craigleith and Craigleith (Feak)/Hailes being significantly less permeable. Earth mortar has similar permeability to Locharbriggs sandstone. Granodiorite and whinstone are indistinguishable but of significantly lower permeability than the rest.

Table 2 also shows the vapour diffusion resistance factor $\mu_{\text {dry }}$ and $\mu_{\text {wet }}$, defined as the water vapour permeability of air divided by that of the material, which indicates how much greater the vapour resistance of the material is compared to an equally thick layer of still air at the same temperature. The water vapour permeability of air at $23{ }^{\circ} \mathrm{C}$ and $1000 \mathrm{mbar}$ atmospheric pressure is given as $1.8 \times 10^{-10} \mathrm{~kg} /(\mathrm{m}$ $\sec \mathrm{Pa}$ ) [57]. Because of the inverse relationship between water vapour permeability and vapour diffusion resistance factor, the confidence intervals for the latter cannot be simply calculated from the former and are not shown in Table 2.

\subsection{Sorptivity and water absorption coefficient}

Table 2 shows that the sorptivity $S$ and water absorption coefficient $A$ cover a 1600 -fold range and are highest for the mortars, reflecting their high porosity and open texture, with an increasing trend with both decreasing hydraulicity and carbonation, and lowest for the very dense whinstone and granodiorite, whose sorptivity is less than $10 \%$ that of the lowest sandstone. Using the significance criterion, the materials may be grouped in the following order: hot- 
mix lime mortar $>$ all NHL mortars $>$ Hazeldean, Locharbriggs and Giffnock sandstones $>$ Craigleith (Feak)/Hailes sandstone $>$ Craigleith sandstone $>$ Scottish whinstone and Crathes granodiorite.

\subsection{Hygroscopic sorption}

Table 3 shows the mean equilibrium moisture content achieved by each material at each measured $\mathrm{RH}$ under successive sorption and desorption, and Fig. 4 shows one exemplar graph of moisture content against $\mathrm{RH}$. Hysteresis is clearly visible, with the desorption (downcurve) at higher moisture content than the sorption (upcurve): every material showed some hysteresis. A sample contamination problem with the Scottish whinstone gave unfeasibly high moisture contents under desorption so these are omitted from the table. It may be noted that IEA [45] gives a curvefitting equation, relating moisture content $\theta$ to $\mathrm{RH} \phi$

$\theta=\phi /\left(a \phi^{2}+b \phi+c\right)$

whereas WUFI uses linear interpolation from a data table analogous to Table 3. However, detailed discussion of curve fitting is beyond the scope of this paper.
Table 3 suggests that earth mortar has the highest affinity for moisture followed by all the uncarbonated NHL mortars and both hot-mix mortars, and then all the carbonated NHL mortars. The sandstones come next with Crathes granodiorite having the lowest affinity.

\subsection{Porosity}

Figures 5, 6, 7 and 8 show the pore size distributions in a form where the vertical axis is a quantitative measure of the volume of pores of the size given on the (logarithmic scale) horizontal axis, but note the different scales. It can be seen that in some cases there is non-zero intrusion at the large pore size end, which can be attributed to surface irregularities in the samples or tiny amounts of air trapped between the sample and the cell wall, and can be neglected.

Additionally, the curve for the earth mortar shows zero intrusion for small diameters, which suggests that the specimen collapsed under the high intruding mercury pressure.

In the uncarbonated state (Fig. 5a) the NHL mortars show a bimodal distribution with peaks at $0.5 \mu \mathrm{m}$ and $3.7 \mu \mathrm{m}$ (NHL2), at $0.09 \mu \mathrm{m}$ and $1.4 \mu \mathrm{m}$ (NHL3.5) and

Table 3 Equilibrium moisture content $(\mathrm{g} / \mathrm{kg}$ ) at each measured $\mathrm{RH}$ (means of 3 specimens)

\begin{tabular}{|c|c|c|c|c|c|c|c|c|c|c|c|}
\hline \multirow[t]{2}{*}{ Measured RH (\%) } & \multicolumn{5}{|c|}{ Sorption } & \multirow[b]{2}{*}{100} & \multicolumn{5}{|c|}{ Desorption } \\
\hline & 33 & 53 & 72 & 81 & 89 & & 90 & 81 & 72 & 52 & 31 \\
\hline NHL2 mortar uncarbonated & 3.64 & 5.16 & 7.49 & 9.22 & 13.00 & - & 13.00 & 11.34 & 11.01 & 9.10 & 7.34 \\
\hline NHL2 mortar carbonated & 3.14 & 4.37 & 5.50 & 6.08 & 7.59 & - & 7.59 & 6.68 & 6.53 & 5.62 & 4.52 \\
\hline NHL3.5 mortar uncarbonated & 3.57 & 5.39 & 8.29 & 10.28 & 15.17 & - & 15.17 & 12.99 & 12.53 & 9.94 & 7.26 \\
\hline NHL3.5 mortar carbonated & 3.45 & 4.56 & 5.50 & 6.34 & 8.24 & - & 8.24 & 6.64 & 6.33 & 5.28 & 4.26 \\
\hline NHL5 mortar uncarbonated & 3.54 & 5.40 & 8.58 & 11.10 & 16.07 & - & 16.07 & 13.97 & 13.39 & 10.93 & 7.31 \\
\hline NHL5 mortar carbonated & 2.39 & 3.54 & 4.83 & 5.53 & 6.92 & - & 6.92 & 5.85 & 5.64 & 4.81 & 3.44 \\
\hline Hot-mix mortar uncarbonated & 8.11 & 9.14 & 8.65 & 10.25 & 14.86 & 25.97 & 21.20 & 15.08 & 12.60 & 10.04 & 7.22 \\
\hline Hot-mix mortar carbonated & 5.86 & 6.98 & 8.60 & 9.73 & 12.70 & 21.43 & 16.75 & 13.90 & 12.41 & 10.23 & 7.76 \\
\hline Earth mortar & 6.91 & 9.47 & 13.54 & 16.93 & 24.83 & 39.06 & 31.23 & 18.68 & 14.57 & 10.49 & 7.80 \\
\hline Craigleith sandstone & 1.88 & 2.65 & 3.60 & 4.29 & 5.43 & 8.21 & 6.21 & 5.00 & 4.24 & 2.99 & 2.02 \\
\hline Craigleith (Feak)/Hailes sandstone & 1.10 & 1.52 & 2.22 & 2.71 & 3.84 & 6.07 & 4.39 & 3.32 & 2.78 & 1.87 & 1.26 \\
\hline Giffnock sandstone & 1.37 & 2.06 & 4.30 & 6.39 & 10.53 & 19.36 & 11.86 & 6.65 & 5.07 & 2.58 & 2.13 \\
\hline Locharbriggs sandstone & 2.87 & 3.70 & 4.65 & 5.14 & 6.59 & 9.22 & 7.12 & 5.62 & 4.80 & 3.90 & 3.08 \\
\hline Hazeldean sandstone & 0.51 & 0.74 & 0.92 & 1.06 & 1.29 & 2.30 & 1.47 & 1.12 & 1.01 & 0.74 & 0.52 \\
\hline Crathes granodiorite & 0.77 & 1.04 & 1.04 & 1.11 & 1.18 & 1.76 & 1.25 & 1.07 & 1.06 & 0.93 & 0.76 \\
\hline Scottish whinstone & 3.55 & 4.86 & 7.34 & 7.85 & 8.43 & 9.07 & - & - & - & - & - \\
\hline
\end{tabular}




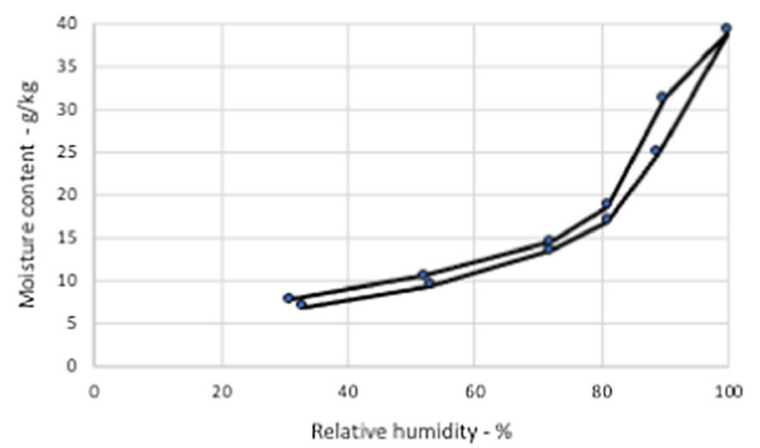

Fig. 4 Graph of moisture content $\theta$ against relative humidity $\phi$ showing the sorption and desorption curves for earth mortar (each point is the mean of three measurements)
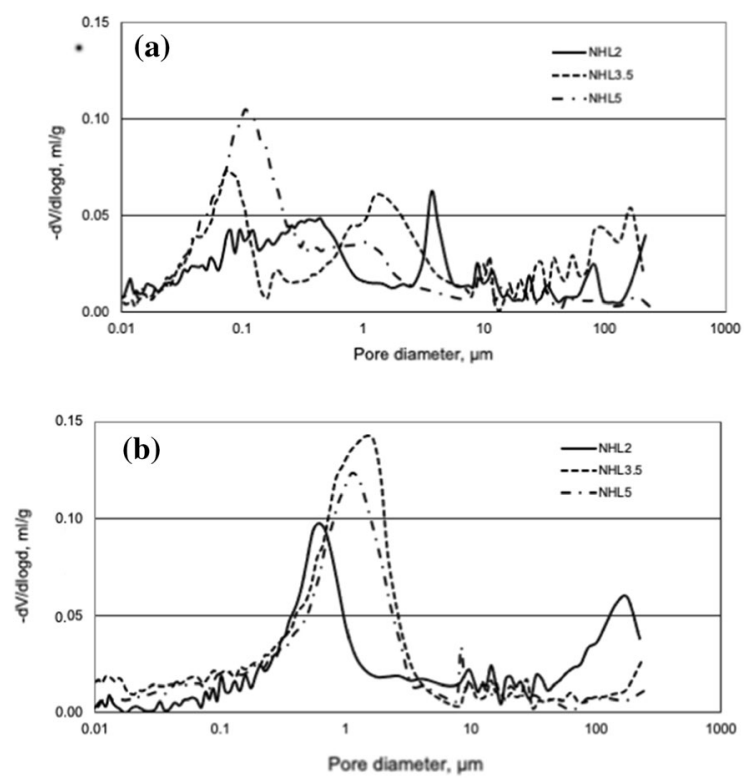

Fig. 5 Pore size distributions of the NHL mortars a uncarbonated, $\mathbf{b}$ carbonated

at $0.1 \mu \mathrm{m}$ and $1.2 \mu \mathrm{m}$ (NHL5). The finer pores are probably those within dicalcium silicate hydrate and the coarser pores those associated with calcium hydroxide. However, after carbonation (Fig. 5b) the distributions change to a single peak at $0.7 \mu \mathrm{m}$ (NHL2), $1.6 \mu \mathrm{m}$ (NHL3.5) and $1.3 \mu \mathrm{m}$ (NHL5). The poorly defined pore size distribution above $10 \mu \mathrm{m}$ probably arises from the interstices between sand particles.

The hot-mixed lime mortars show a similar distribution (Fig. 6) with the peak around $0.15-0.2 \mu \mathrm{m}$ corresponding to the binder porosity and that around $30 \mu \mathrm{m}$ corresponding to the pores between sand particles. Carbonation has a different effect on these mortars which contain no silicate, with the appearance of a shoulder indicating coarsening of the binder porosity. Presumably the earth mortar would have shown a similar bimodal distribution but collapse of the sample hides the lower peak.

The sandstones (Fig. 7) all exhibit a well-defined main peak, around 28, 25 and $20 \mu \mathrm{m}$ in Locharbriggs, Hazeldean and Giffnock respectively, whilst in Craigleith and Craigleith (Feak)/Hailes the main peak reflects finer pores around 2 and $8 \mu \mathrm{m}$ respectively. Whinstone and granodiorite (Fig. 8) have very low porosities with fine pores around 0.03 and $0.4 \mu \mathrm{m}$ respectively and an irregular distribution of pores between 10 and $150 \mu \mathrm{m}$.

Table 4 compares the total porosities of each material in the range of pore sizes only up to $100 \mu \mathrm{m}$, in order to avoid any possible skewing of the data due to the experimental issue mentioned above. The results for the mortars are divided into pore sizes below or above $10 \mu \mathrm{m}$, corresponding to the binder porosity and inter-aggregate particle spaces, respectively.

As expected, the lime mortars have high total porosity and the granodiorite and whinstone have low porosity, consistent with the high and low values of $\theta_{\text {sat }}$ (Table 2), whilst the sandstones occupy the middle range of porosity but with notable differences, which also reflect the various distributions in Figs. 5, 6, 7 and 8. Craigleith sandstone's low porosity is consistent with its fine texture and good reputation as a durable sandstone. Craigleith (Feak)/Hailes, Locharbriggs, Hazeldean and Giffnock sandstones have progressively higher porosity and the distributions confirm that it is wrong to assume that all sandstones are the same.

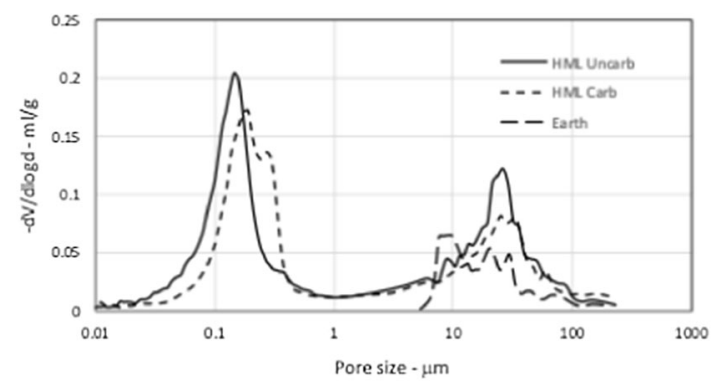

Fig. 6 Pore size distributions of the hot-mixed lime mortars and earth mortar 


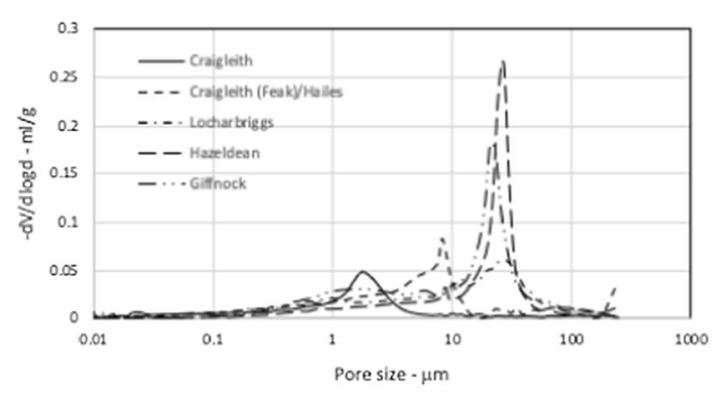

Fig. 7 Pore size distributions of the sandstones

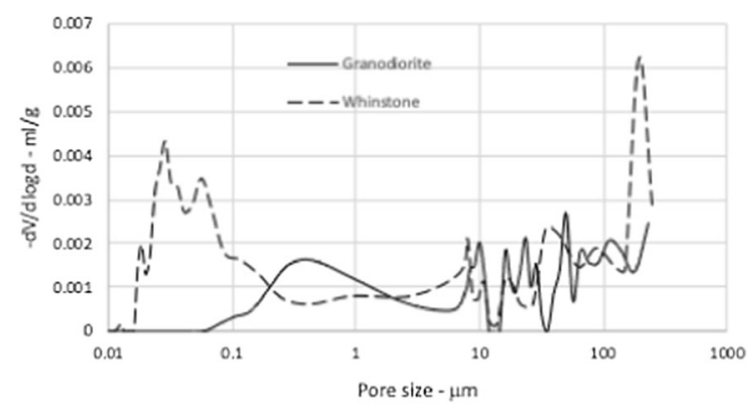

Fig. 8 Pore size distributions of the granodiorite and Scottish whinstone

\section{General discussion}

Comparing the data given in Tables 2 and 4 and Figs. 5-8 with the range of values reported in the literature addresses the question of whether the results are consistent with other work, despite the different materials tested. In this section values of density, thermal conductivity, vapour diffusion resistance factor, water absorption coefficient, hygroscopic sorption, porosity and pore sizes collected from the literature review (Sect. 2.2) are compared for four generic types of material. These are lime mortar (Table 5, categorised into either NHL or hot-mixed, air lime and unspecified, but not into their carbonation state for the reasons discussed in Sect. 2.2), earth mortar (Table 6), sandstone (Table 7) and granite (Table 8). The following actions have been performed to produce the comparisons. (i) Where appropriate, literature values have been converted from the units used in the original sources. (ii) Thermal conductivity is given in the dry state. (iii) Vapour diffusion resistance factor refers to the results of dry cup tests. (iv) Water absorption coefficient, which is not given directly in the WUFI database, has been reverse calculated from the values of the liquid transport
Table 4 Porosity of each material (single determination)

\begin{tabular}{|c|c|c|c|}
\hline Material & Pores $<10 \mu \mathrm{m}$ & Pores $>10 \mu \mathrm{m}$ & Total \\
\hline $\begin{array}{l}\text { Uncarbonated } \\
\text { NHL2 mortar }\end{array}$ & 0.136 & 0.050 & 0.186 \\
\hline $\begin{array}{l}\text { Uncarbonated } \\
\text { NHL3.5 mortar }\end{array}$ & 0.146 & 0.084 & 0.230 \\
\hline $\begin{array}{l}\text { Uncarbonated } \\
\text { NHL5 mortar }\end{array}$ & 0.20 & 0.040 & 0.240 \\
\hline $\begin{array}{l}\text { Carbonated } \\
\text { NHL2 mortar }\end{array}$ & 0.108 & 0.088 & 0.196 \\
\hline $\begin{array}{l}\text { Carbonated } \\
\text { NHL3.5 mortar }\end{array}$ & 0.223 & 0.049 & 0.272 \\
\hline $\begin{array}{l}\text { Carbonated } \\
\text { NHL5 mortar }\end{array}$ & 0.191 & 0.057 & 0.248 \\
\hline $\begin{array}{l}\text { Uncarbonated } \\
\text { hot-mix mortar }\end{array}$ & 0.185 & 0.125 & 0.310 \\
\hline $\begin{array}{l}\text { Carbonated hot- } \\
\text { mix mortar }\end{array}$ & 0.184 & 0.113 & 0.297 \\
\hline Earth mortar & - & 0.080 & $(0.080)$ \\
\hline $\begin{array}{l}\text { Hazeldean } \\
\text { sandstone }\end{array}$ & & & 0.171 \\
\hline $\begin{array}{l}\text { Locharbriggs } \\
\text { sandstone }\end{array}$ & & & 0.156 \\
\hline $\begin{array}{l}\text { Craigleith } \\
\text { sandstone }\end{array}$ & & & 0.081 \\
\hline $\begin{array}{l}\text { Craigleith } \\
\text { (Feak)/Hailes } \\
\text { sandstone }\end{array}$ & & & 0.127 \\
\hline $\begin{array}{l}\text { Giffnock } \\
\text { sandstone }\end{array}$ & & & 0.206 \\
\hline $\begin{array}{l}\text { Scottish } \\
\text { whinstone }\end{array}$ & & & 0.016 \\
\hline $\begin{array}{l}\text { Crathes } \\
\text { granodiorite }\end{array}$ & & & 0.009 \\
\hline
\end{tabular}

suction coefficient $D_{w s}$, water content $w$ and free saturation water content $w_{f}$ quoted there for each material, using Eq. 3 [14].

$D_{w s}=3.8 \times\left(A / w_{f}\right)^{2} \times 1000^{\left(w / w_{f}-1\right)}$

(v) Hygroscopic sorption is expressed as a single parameter, the equilibrium water content at $90 \% \mathrm{RH}$ $\theta_{90}$ obtained by linear interpolation between adjacent measurements.

The NHL mortars in this work are denser and less porous than in other work but the ranges of every other parameter align with those in other work. It should be noted that Fusade et al. [43] report wet cup vapour 
Table 5 Comparison of data for lime mortars

\begin{tabular}{|c|c|c|c|}
\hline Parameter & This work & Other work & References \\
\hline \multicolumn{4}{|l|}{ NHL mortars } \\
\hline Density $\left(\mathrm{kg} / \mathrm{m}^{3}\right)$ & $1800-1975$ & $1600-1830$ & {$[14,44,45]$} \\
\hline Thermal conductivity (dry) & $0.6-0.9$ & $0.7-1.2$ & {$[14,44,45]$} \\
\hline \multicolumn{4}{|l|}{$\mathrm{W} /(\mathrm{mK})$} \\
\hline Vapour diffusion resistance factor (dry cup) & $7-11$ & $6-41$ & {$[14,43,45]$} \\
\hline Water absorption coefficient $\mathrm{kg} /\left(\mathrm{m}^{2} \sqrt{\mathrm{s}}\right)$ & $0.1-0.32$ & $0.04-0.25$ & {$[14,38,43]$} \\
\hline Hygroscopic sorption $\left(\mathrm{kg} / \mathrm{m}^{3}\right.$ at $\left.90 \% \mathrm{RH}\right)$ & $14-31$ & $15-20$ & {$[14]$} \\
\hline Total porosity & $0.19-0.28$ & $0.27-0.37$ & {$[14,43,44]$} \\
\hline \multicolumn{4}{|c|}{ Hot-mixed and air lime mortars, including unspecified lime mortars } \\
\hline Density $\left(\mathrm{kg} / \mathrm{m}^{3}\right)$ & $1750-1875$ & $1340-1810$ & {$[14,35,37,39-42,45]$} \\
\hline Thermal conductivity (dry) & $0.2-0.22$ & $0.35-1.4$ & {$[14,39-41,45]$} \\
\hline \multicolumn{4}{|l|}{$\mathrm{W} /(\mathrm{mK})$} \\
\hline Vapour diffusion resistance factor (dry cup) & 23 & $6-37$ & {$[14,35,39-42,45]$} \\
\hline Water absorption coefficient $\mathrm{kg} /\left(\mathrm{m}^{2} \sqrt{\mathrm{s}}\right)$ & $0.28-0.36$ & $0.008-1.2$ & {$[14,36,37,39-41]$} \\
\hline Hygroscopic sorption $\left(\mathrm{kg} / \mathrm{m}^{3}\right.$ at $\left.90 \% \mathrm{RH}\right)$ & $2.4-2.6$ & $1.7-16$ & {$[14,40,42,45]$} \\
\hline Total porosity & $0.3-0.31$ & $0.26-0.49$ & {$[14,35-37,39-41,45]$} \\
\hline
\end{tabular}

Table 6 Comparison of data for earth/earth mortars

\begin{tabular}{llll}
\hline Parameter & This work & Other work & References \\
\hline Density $\left(\mathrm{kg} / \mathrm{m}^{3}\right)$ & 2000 & $1570-2070$ & {$[14,46,47,61]$} \\
Thermal conductivity (dry) & 0.21 & $0.3-1.35$ & {$[14,46,47,61]$} \\
W/(mK) & & & $7-19$ \\
Vapour diffusion resistance factor & 29 & $0.019-0.26$ & {$[14,46]$} \\
Water absorption coefficient $\mathrm{kg} /\left(\mathrm{m}^{2} \sqrt{\mathrm{s}}\right)$ & - & $2-950$ & {$[14,47]$} \\
Hygroscopic sorption $\left(\mathrm{kg} / \mathrm{m}^{3}\right.$ at $\left.90 \% \mathrm{RH}\right)$ & 5.0 & $0.26-0.41$ & {$[14,46,47]$} \\
Total porosity & $>0.08$ & {$[14,46,47,61]$} \\
\hline
\end{tabular}

diffusion resistance factor, which is always less than the dry cup value. Hygroscopic sorption extends to a higher water content than given in WUFI [14] which may be due to the latter reporting "hydraulic lime" mortar, which has a different binder composition from NHL. Considering the hot-mixed, air lime and unspecified lime mortars, the range of every parameter is narrower than in other work, although the lowest density and highest porosity both come from a single air lime mortar tested by Lopez et al. [35] and the next values of $1550 \mathrm{~kg} / \mathrm{m}^{3}$ and 0.40 respectively [37] are nearer to those found here. Pore diameters for four uncarbonated air lime mortars are given as $0.3-0.5 \mu \mathrm{m}$ and 20-80 $\mu \mathrm{m}$ [37], rather coarser than those shown in Fig. 6.

Compared to the earth mortar, the earth bricks of Cagnon et al. [46] have similar density but higher thermal conductivity, lower vapour diffusion resistance factor and much higher hygroscopic sorption, whilst the clay mortar in WUFI [14] has lower density, higher thermal conductivity, lower vapour diffusion resistance factor and higher hygroscopic sorption. This suggests that the high sand content $(66 \%)$ of the earth mortar tested in this work may make the comparison with those of Cagnon et al. (33-43\% sand) inappropriate. Additionally values for water 
Table 7 Comparison of data for sandstones

\begin{tabular}{llll}
\hline Parameter & This work & Other work & References \\
\hline $\begin{array}{l}\text { Density }\left(\mathrm{kg} / \mathrm{m}^{3}\right) \\
\text { Thermal conductivity }(\mathrm{dry})\end{array}$ & $2200-2450$ & $1925-2490$ & {$[14,48]$} \\
$\mathrm{W} /(\mathrm{mK})$ & $1.1-1.7$ & $1.0-3.5$ & {$[14,45,49-51]$} \\
Vapour diffusion resistance factor $(\mathrm{dry}$ cup) & $30-150$ & & \\
Water absorption coefficient $\mathrm{kg} /\left(\mathrm{m}^{2} \sqrt{\mathrm{s}}\right)$ & $0.008-0.11$ & $0.003-0.9$ & {$[14,45,49,50]$} \\
Hygroscopic sorption $\left(\mathrm{kg} / \mathrm{m}^{3}\right.$ at $\left.90 \% \mathrm{RH}\right)$ & $2.9-23$ & $2-43$ & {$[14,48,50,51,66]$} \\
Total porosity & $0.08-0.2$ & $0.10-0.31$ & {$[14,48,50,67,68]$} \\
\hline
\end{tabular}

Table 8 Comparison of data for granites

\begin{tabular}{|c|c|c|c|}
\hline Parameter & This work & Other work & References \\
\hline Density $\left(\mathrm{kg} / \mathrm{m}^{3}\right)$ & 2650 & $2450-3100$ & {$[14,45,52]$} \\
\hline Thermal conductivity (dry) & 2.1 & $1.6-4.1$ & {$[14,45]$} \\
\hline \multicolumn{4}{|l|}{$\mathrm{W} /(\mathrm{mK})$} \\
\hline Vapour diffusion resistance factor (dry cup) & 1200 & $54-60$ & {$[14,45]$} \\
\hline Water absorption coefficient $\mathrm{kg} /\left(\mathrm{m}^{2} \sqrt{ } \mathrm{s}\right)$ & 0.011 & 0.008 & [14] \\
\hline Hygroscopic sorption $\left(\mathrm{kg} / \mathrm{m}^{3}\right.$ at $\left.90 \% \mathrm{RH}\right)$ & 3.1 & 9 & [14] \\
\hline Total porosity & 0.011 & $0.095-0.13$ & {$[14,52]$} \\
\hline
\end{tabular}

absorption coefficient of clay mortar and clay plaster are given by WUFI [14] and Lima et al. [47] respectively, which place it as similar to the NHL and hot-mix lime mortars. The much higher hygroscopic sorption of clay plaster [47] was estimated from a test involving a much larger surface area of specimen exposed to water vapour.

For sandstone, the range of values of every measured parameter is narrower than the range reported in other work, except for the total porosity of Craigleith sandstone which is the lowest of all. Pore diameters are given as $0.1-0.3 \mu \mathrm{m}$ and $2-10 \mu \mathrm{m}$ for German sandstones [46] and 10-100 $\mu \mathrm{m}$ for Czech sandstones [50], a wider range than shown in Fig. 6.

For granite, density and thermal conductivity are within the range of other work and water absorption coefficient is similar but hygroscopic sorption and porosity are significantly less than WUFI [14], which are consistent with granodiorite's much higher vapour diffusion resistance factor. Pore diameters are not given.

Because the values of each material property shown by these Scottish masonry materials are distributed more narrowly than the values found in the literature, practitioners should use the values presented here in hygrothermal simulations. Additionally, because most properties of lime mortars are similar in the uncarbonated and carbonated states, it is to be expected that ignorance of the extent of carbonation in a wall will not cause errors in the results of a simulation.

Whilst the previous discussion shows that the results are reasonable in the context of other data, it could be argued that the material sampling protocol gives no indication of the variability of each material. Replicate tests on each sample of material give an indication of handling and testing variability but not the variability between different parts of a quarry, for example, which would require a more extensive sampling and testing programme than this. Additionally, the lime mortars that were tested all used contemporary rather than historic binders. To obtain information on the properties of existing mortars in historic buildings would require careful non-destructive experimental work which is beyond the scope of this initial laboratory investigation. Thus, this investigation has given indicative, but not necessarily representative, values of the hygrothermal properties. 


\section{Conclusions}

This paper has presented, for the first time, a comprehensive set of hygrothermal property data for selected historic and contemporary masonry materials relevant to traditional masonry construction in Scotland. Thermal conductivity, water vapour permeability, sorptivity, water absorption coefficient, hygroscopic sorption, density and porosity were all determined experimentally. The results allow the materials to be grouped into three categories. Natural hydraulic lime mortars, hot-mixed quicklime mortar and earth mortar all show comparatively low density, high porosity, low thermal conductivity, high water vapour permeability and variable but generally high hygroscopic sorption. Craigleith, Craigleith (Feak)/Hailes and Giffnock sandstones, no longer available but obtained from conservation works on historic buildings, and Locharbriggs and Hazeldean sandstones (from current production) all show intermediate values of these properties. Crathes granodiorite and Scottish whinstone (from current production) show high density, low porosity, high thermal conductivity, low water vapour permeability and (for the granodiorite only) low hygroscopic sorption.

Acknowledgements The mercury intrusion porosimetry was performed by The University of Dundee. Petrographic analysis was performed by the Scottish Lime Centre. Gavin Spowart, Lee Masson and Graham Sorley assisted with some of the experimental work. Suppliers of materials and building owners are gratefully thanked, especially Joanne Curran and Gary Jebb.

Funding Part of this work was financially supported by Historic Environment Scotland.

Availability of data All measured data will be made available on request to the author.

\section{Delcarations}

Conflicts of interest The author declares that no conflict of interest exists in this paper.

Open Access This article is licensed under a Creative Commons Attribution 4.0 International License, which permits use, sharing, adaptation, distribution and reproduction in any medium or format, as long as you give appropriate credit to the original author(s) and the source, provide a link to the Creative Commons licence, and indicate if changes were made. The images or other third party material in this article are included in the article's Creative Commons licence, unless indicated otherwise in a credit line to the material. If material is not included in the article's Creative Commons licence and your intended use is not permitted by statutory regulation or exceeds the permitted use, you will need to obtain permission directly from the copyright holder. To view a copy of this licence, visit http://creativecommons.org/licenses/by/4.0/.

\section{References}

1. May N, Sanders C (2016) Moisture in buildings: an integrated approach to risk assessment and guidance White Paper BSI/UK/899/ST/0816/EN/HL. British Standards Institution, London

2. Hall MR, Allinson D (2010) Heat and mass transport processes in building materials. In: Hall MR (ed) Materials for energy efficiency and thermal comfort in buildings. Woodhead Publishing, Cambridge UK, pp 3-53

3. Heritage E (2011) Energy efficiency and historic buildings. English Heritage, London

4. Jenkins M, Curtis R (2014) Improving energy efficiency in traditional buildings. Inform Guide. Historic Scotland, Edinburgh

5. May N, Rye C (2012) Responsible retrofit of traditional buildings. Sustainable Traditional Buildings Alliance, London

6. Prince's Regeneration Trust (2010) The green guide for historic buildings: How to improve the environmental sustainability of listed and historic buildings. The Stationery Office, London

7. Urquhart D (2006) Safeguarding Glasgow's stone-built heritage: skills and materials requirements: executive summary. Scottish Stone Liaison Group, Roslin UK

8. Bruhns H, Steadman P, Herring H (2000) A database for modelling energy use in the non-domestic building stock of England and Wales. Appl Energy 66:277-297

9. Department of Energy and Climate Change (2008) The Climate Change Act 2008. HM Government, London

10. Shrubsole C, Macmillan A, Davies M, May N (2014) 100 unintended consequences of policies to improve the energy efficiency of the UK housing stock. Indoor and Built Environment 23:340-352. https://doi.org/10.1177/ $1420326 X 14524586$

11. Sharpe RA, Thornton CR, Vasilis N, Osborne NJ (2015) Higher energy efficient homes are associated with increased risk of doctor diagnosed asthma in a UK subpopulation. Environ Int 75:234-244. https://doi.org/10.1016/j.envint. 2014.11.017

12. Künzel HM, Karagiozis A (2010) Hygrothermal behaviour and simulation in buildings. In: Hall MR (ed) Materials for energy efficiency and thermal comfort in buildings. Woodhead Publishing, Cambridge UK, pp 54-76

13. Little J, Ferraro C, Arregi B (2015) Assessing risks in insulation retrofits using hygrothermal software tools, Technical Report 15, Edinburgh, Historic Environment Scotland

14. WUFI ${ }^{\circledR}$ (2021) Wärme und Feuchte Instanzionär. www. wufi.de. Accessed 11 February 2021

15. DELPHIN (2021) www.bauklimatik-dresden.de/delphin/. Accessed 11 February 2021 
16. Ministry of Housing Communities Local Government (2019) Resistance to moisture in buildings: Using numerical simulation to assess moisture risk in retrofit constructions. https://www.gov.uk/government/publications/resistanceto-moisture-in-buildings. Accessed 11 February 2021

17. Kent D (2020) Technical Notes. The SPAB Magazine (Summer) 60-63

18. Marincioni V, Marra G, Altamirano-Medina H (2018) Development of predictive models for the probabilistic moisture risk assessment of internal wall insulation. Build Environ 137:257-267. https://doi.org/10.1016/j.buildenv. 2018.04.001

19. HES (2017) Scotland's traditional building materials: A consideration of current provision, challenges and opportunities. Historic Environment Scotland, Edinburgh

20. Gibbons P (1995) Preparation and use of lime mortars. Technical Advisory Note TAN 1, Historic Scotland, Edinburgh

21. BSI (2015) Building lime. Definitions, specifications and conformity criteria, BS EN 459-1:2015, British Standards Institution, London

22. Snow J (2015) Hot-mixed lime mortars. Inform Guide, Historic Environment Scotland, Edinburgh

23. Torney C, Schmidt A, Graham C (2020) A data driven approach to understanding historic mortars in Scotland. Technical Paper 32, Historic Environment Scotland, Edinburgh

24. Curtis R (2015) Clay mortars for masonry buildings. Inform Guide, Historic Environment Scotland, Edinburgh

25. Copsey N (2019) Hot mixed lime and traditional mortars. The Crowood Press, Marlborough UK

26. McMillan AA (1997) Quarries of Scotland. Technical Advisory Note TAN 12, Historic Scotland, Edinburgh

27. EGS (2020) www.edinburghgeolsoc.org/downloads/ rigsleaflet_craigleitha4.pdf. Accessed 11 February 2021

28. GSNI (2021) Natural Stone- Database. Geological Survey of Northern Ireland, Belfast. www.stonedatabase.com. Accessed 11 February 2021

29. Hughes JJ, Tennent N (2008) The petrography of the Giffnock sandstone from the interior of the Kelvingrove Art Gallery and Museum, Glasgow. In: Lukaszewicz JW, Niemcewicz P (eds) Proceedings of the 11th International Congress on Deterioration and Conservation of Stone. Nicolaus Copernicus University Press, Torun Poland, pp 651-659

30. Hutton Stone (2020). www.huttonstone.co.uk. Accessed 11 February 2021

31. Rubislaw (2021) https://en.wikipedia.org/wiki/Rubislaw_ quarry. Accessed 11 February 2021

32. McMillan AA, Gillanders RJ, Fairhurst JA (1999) Building stones of Edinburgh. Edinburgh Geological Society, Edinburgh

33. Tradstocks (2021). www.tradstocks.squarespace.com. Accessed 11 February 2021

34. Künzel HM (1995) Simultaneous heat and moisture transport in building components: One- and two-dimensional calculation using simple parameters. Fraunhofer Institute of Building Physics Holzkirchen

35. Lopez O, Torres I, Guimares AS, Delgado JMPQ, de Freitas VP (2017) Inter-laboratory variability results of porous building materials hygrothermal properties. Constr Build
Mater 156:412-423. https://doi.org/10.1016/j.conbuildmat. 2017.08.184

36. Loureiro AMS, da Paz SPA, Veiga MR, Angelica RS (2020) Investigation of historical mortars from Belem do Para. Northern Brazil Construction and Building Materials 233:117284. https://doi.org/10.1016/j.conbuildmat.2019. 117284

37. Faria P, Henriques F, Rato V (2008) Comparative evaluation of lime mortars for architectural conservation. J Cult Herit 9:338-346. https://doi.org/10.1016/j.culher.2008.03. 003

38. Veiga MR, Fragata A, Velosa AL, Magalhaes AC, Margalha G (2010) Lime-based mortars: viability for use as substitution renders in historical buildings. Int J Archit Herit 4:177-195. https://doi.org/10.1080/15583050902914678

39. Vejmelkova E, Pernicova R, Sovjak R, Cerny R (2009) Properties of innovative renders on a lime basis for the renovation of historical buildings. WIT Trans Built Environ 109:221-229. https://doi.org/10.2495/STR090201

40. Cachova M, Vejmelkova E, Konakova D, Zumar J, Keppert M, Reiterman P, Cerny R (2016) Application of ceramic powder as supplementary cementitious material in lime plasters. Mater Sci (Medziagotyra) 22:440-444. https://doi. org/10.5755/j01.ms.22.3.7433

41. Cerny R, Kunca A, Tydlitat V, Drchalova J, Rovnanikova P (2006) Effect of pozzolanic admixtures on mechanical, thermal and hygric properties of lime plasters. Constr Build Mater 20:849-857. https://doi.org/10.1016/j.conbuildmat. 2005.07.002

42. Padfield T (1998) The role of absorbent building materials in moderating changes of relative humidity. $\mathrm{PhD}$ Thesis, Technical University of Denmark

43. Fusade L, Viles H, Wood C, Burns C (2019) The effect of wood ash on the properties and durability of lime mortar for repointing damp historic buildings. Constr Build Mater 212:500-513. https://doi.org/10.1016/j.conbuildmat.2019. 03.326

44. Grilo J, Faria P, Veiga R, Santos Silva A, Velosa A (2014) New natural hydraulic lime mortars - physical and microstructural properties in different curing conditions. Constr Build Mater 54:378-384. https://doi.org/10.1016/j. conbuildmat.2013.12.078

45. IEA (1991) Catalogue of material properties: Annex 14, volume 3, Condensation and Energy. International Energy Agency, Paris

46. Cagnon H, Aubert JE, Coutand M, Magniont C (2014) Hygrothermal properties of earth bricks. Energy Build 80:208-217. https://doi.org/10.1016/j.enbuild.2014.05.024

47. Lima J, Faria P, Santos Silva A (2020) Earth Plasters: The Influence of Clay Mineralogy in the Plasters' Properties. Int J Archit Herit 14(7):948-963. https://doi.org/10.1080/ 15583058.2020.1727064

48. Zhao J, Plagge R (2015) Characterization of hygrothermal properties of sandstones - Impact of anisotropy on their thermal and moisture behaviors. Energy and Buildings 107:479-494. https://doi.org/10.1016/j.enbuild.2015.08. 033

49. Koci V, Madera J, Fort J, Zumar J, Pavlikova M, Pavlik Z, Cerny R (2014) Service life assessment of historical building envelopes constructed using different types of 
sandstone: a computational analysis based on experimental input data. Sci World J 1:1-12

50. Vejmelkova E, Keppert M, Reiterman P, Cerny R (2013) Mechanical, hygric and thermal properties of building stones. WIT Trans Built Environ 131:357-367. https://doi. org/10.2495/STR130301

51. Mukhopadhyaya P, Kumaran MK, Lackey J, Normandin N, van Reenen D, Tariku F (2007) Hygrothermal properties of exterior claddings, sheathing boards, membranes and insulation materials for building envelope design. In Proceedings of Thermal Performance of the Exterior Envelopes of Whole Buildings X, Clearwater, FL, pp 1-16

52. Ozcelik Y, Ozguven A (2014) Water absorption and drying features of different natural building stones. Constr Build Mater 63:257-270. https://doi.org/10.1016/j.conbuildmat. 2014.04.030

53. BSI (2010) Building lime. Part 2 Testing methods, BS EN 459-2:2015, British Standards Institution, London

54. Forster AM, Szadurski EM, Banfill PFG (2014) Deterioration of natural hydraulic lime mortars, I: Effects of chemically accelerated leaching on physical and mechanical properties of uncarbonated materials. Constr Build Mater 72:199-207. https://doi.org/10.1016/j.conbuildmat.2014.09.015

55. Kaye GWC, Laby TH (1966) Tables of physical and chemical constants. Longman, London

56. ASTM (2014) Standard test method for determination of thermal conductivity of soil and soft rock by thermal needle probe procedure. ASTM D5334-14, ASTM International, West Conshohocken, USA

57. BSI (2001) Hygrothermal performance of building materials and products-Determination of water vapour transmission properties. BS EN ISO 12572:2001, British Standards Institution, London

58. BSI (2013) Hygrothermal performance of building materials and products-Determination of hygroscopic sorption properties. BS EN ISO 12571:2013, British Standards Institution, London

59. Hall C, Hoff WD (2002) Water transport in brick, stone and concrete. Taylor and Francis, London
60. BSI (2002) Hygrothermal performance of building materials and products-Determination of water absorption coefficient by partial immersion. BS EN ISO 15148:2002, British Standards Institution, London

61. Faria P, Santos T, Aubert J-E (2016) Experimental Characterization of an Earth Eco-Efficient Plastering Mortar. J Mater Civ Eng 28:1. https://doi.org/10.1061/(ASCE)MT. 1943-5533.0001363

62. BSI (2007) Natural stone test methods. Petrographic examination. BS EN 12407:2007, British Standards Institution, London

63. McBride EF (1963) A classification of common sandstones. J Sediment Petrol 33:664-669

64. Davies OL (1957) Design and analysis of industrial experiments. Oliver and Boyd, London

65. Chatfield C (1970) Statistics for technology. Chapman and Hall, London

66. Krus M (1996) Moisture transport and storage coefficients of porous mineral building materials: Theoretical principles and new test methods. Fraunhofer IRB Verlag, Stuttgart

67. Abid M, Hammerschmidt U, Kohler J (2014) Temperature and moisture dependent thermophysical properties of Sander sandstone. Int J Therm Sci 86:88-94. https://doi.org/10. 1016/j.ijthermalsci.2014.06.021

68. Makhlouf NN, Maskell D, Marsh A, Natarajan S, Dabaieh M, Afify MM (2019) Hygrothermal performance of vernacular stone in a desert climate. Constr Build Mater 216:687-696. https://doi.org/10.1016/j.conbuildmat.2019.04.244

69. Haluk Selim H, Karakas A, Coruk O (2019) Investigation of engineering properties for usability of Lefke stone (Osmaneli/ Bilecik) as building stone. Bull Eng Geol Env 78:6047-6059. https://doi.org/10.1007/s10064-019-01520-3

Publisher's Note Springer Nature remains neutral with regard to jurisdictional claims in published maps and institutional affiliations. 